\title{
The Global Impacts of Biofuel Mandates
}

\author{
Thomas W. Hertel*, Wallace E. Tyner** and Dileep K. Birur**
}

The rise in world oil prices, coupled with heightened interest in the abatement of greenhouse gas emissions, led to a sharp increase in biofuels production around the world. Previous authors have devoted considerable attention to the impacts of these policies on a country-by-country basis. However, there are also strong interactions among these programs, as they compete in world markets for feedstocks and ultimately for a limited supply of global land. In this paper, we offer the first global assessment of biofuel programs-focusing particularly on the EU and US. We begin with an historical analysis of the period 2001-2006, which also permits us to validate the model. We then conduct an ex ante analysis of mandates in the year 2015. We find that if these mandates are indeed fulfilled the impact on global land use could be substantial, with potentially significant implications for greenhouse gas emissions.

\section{INTRODUCTION}

The rise in world oil prices, coupled with heightened interest in the abatement of greenhouse gas emissions and concerns about energy security, has led to a sharp increase in biofuels production and related policy measures. Biofuel mandates in the United States (US) and the European Union (EU) have commanded the most interest. Studies of the impacts of the US biofuel industry generally have concluded that large programs such as those included in the "Energy Independence and Security Act of 2007" would lead to food price increases, use of a large fraction of US corn for ethanol, and bring about a consequent decline of corn use

The Energy Journal, Vol. 31, No. 1. Copyright @2010 by the IAEE. All rights reserved.

* Corresponding author: T.W. Hertel. Executive Director, Center for Global Trade Analysis. Email: hertel@purdue.edu.

** All authors are with the Department of Agricultural Economics, Purdue University, 403 W. State St., KRAN, West Lafayette, IN 47907, USA.

The authors gratefully acknowledge research support from the US Environmental Protection Agency, the US Department of Energy, and Argonne National Labs. The authors are thankful to Editor, Professor James Smith and four anonymous reviewers for their valuable comments and suggestions. Any remaining errors are the authors' responsibility. 
for domestic feed and industrial uses and exports (Tokgoz et al., 2007). Studies of the EU have concluded that the EU biofuel directive's 2010 target will not likely be reached. However, they suggest that, in attempting to achieve these targets, there will be an enormous increase in demand for biofuel feedstocks and a substantially larger agricultural trade deficit (Banse et al., 2008; Tokgoz et al., 2007). Other studies (McCarl et al., 2005; Fargione et al., 2008; Searchinger et al., 2008) have examined the Greenhouse Gas Emissions (GHG) impacts of land use change due to biofuels programs, and there is currently a hot debate on that topic.

These studies have typically examined the impacts of biofuels policies for one region; e.g., US or EU. However, biofuels compete in world markets for feedstocks and ultimately for a limited supply of global land. This is particularly important in the case of the US and EU, since both regions are big players in international agricultural trade. The biofuel mandates in these two regions are anticipated to have a large impact on imports as well as exports, so it is important to consider how the two sets of policies are likely to interact through global markets. Which of these policies will have a greater impact on global land use? What impact will these combined policies have on third countries - particularly trade and land use impacts in the developing world? In this paper we explore these issues for both EU and US policies with an emphasis on production, trade, and land-use changes.

After a brief review of biofuel policies in the US and EU, we discuss our methodology for analyzing their interaction in global markets. This involves a specially designed global trade model which places at its center the emerging biofuels sectors, carefully developing their links to the energy and agriculture economies. Since biofuel feedstocks compete for land with other agriculture and forestry uses, we also pay special attention to land markets. Indeed, the indirect land use impacts of biofuel policies are at the heart of the current debate over their potential contributions to Greenhouse Gas (GHG) mitigation (Fargione et al., 2008; Searchinger et al., 2008).

One important feature of the model and data used for this analysis that is not in previous work (including our own) is the incorporation of by-products directly into the GTAP Computable General Equilibrium (CGE) model of global trade. That is, in the US, the main by-product of producing ethanol from corn is distillers dried grains with solubles (DDGS), which is used as an animal feed. DDGS has been added as a co-product with ethanol and substitutes for corn and other feedstuffs in animal feeds in the model. Similarly, the meal co-products with vegetable oils have been added. Price, production, and land use impacts are substantially reduced compared to the analysis without considering by-products.

One of the most important criticisms of CGE analysis is the limited validation of these models against historical data. In order to address this concern in our present paper, we begin by validating our model over the historical period: 20012006. This was a period of extremely rapid growth in biofuels production in both the EU and the US, and it offers an interesting "proving ground" for the model. We also use this historical simulation to estimate the critical elasticity of substitution 
between biofuels and petroleum products. This is an important and novel aspect of the present paper. Following this ex post analysis, we move on to an ex ante analysis of future biofuel mandates in these two regions. Our focus is particularly on the interplay between the two sets of policies, and their impacts on third countries. The paper concludes with a summary of the major findings as well as a discussion of the limitations of our current work and directions for future research in this area.

\section{POLICY BACKGROUND}

US Programs: Interest in liquid biofuels initially came about in the late 1970s as OPEC reduced crude oil supplies on the world market and fuel prices increased substantially. Both the US and Brazil launched subsidized ethanol programs during this period. Until 2006, Brazil was the global leader in ethanol production - in large part due to the relatively greater efficiency of sugar cane-based ethanol conversion. However, as a result of government policies and higher oil prices, ethanol production in the US has recently surged, and it now exceeds that in Brazil. Subsidization of ethanol in the US began with the Energy Policy Act of 1978. At the time, the main arguments that were used to justify the subsidy were enhanced farm income and, to a lesser extent, energy security. In 1990, the Clean Air Act was passed, which required vendors of gasoline to have a minimum oxygen percentage in their product. Adding oxygen enables the fuel to burn cleaner, so a cleaner environment became another important justification for ethanol subsidies. By requiring the oil industry to meet an oxygen percentage standard instead of a direct clean air standard, the policy favored additives like ethanol that contain a high percentage of oxygen by weight. However, methyl tertiary butyl ether (MTBE), a competitor for oxygenation, was generally cheaper than ethanol, so it continued to be the favored way of meeting the oxygen requirements.

The growth in MTBE use was short-lived, as it began to crop up in water supplies in several regions in the country. Since MTBE is highly toxic, it was gradually banned on a state-by-state basis. That left ethanol as the major source of added oxygen, and this contributed to ethanol selling at a significant premium, relative to gasoline. Indeed, ethanol prices peaked at \$3.58/gallon in June, 2006, shortly after the MTBE ban was complete. Much, but not all, of this huge price increase was due to this change in rules and legal liability. Since that time, the price of ethanol has been falling, relative to gasoline, as the demand for ethanol as an additive has become satiated. ${ }^{1}$ During the 20 years between 1983 and 2003 the US ethanol subsidy varied between 40 and 60 cents per gallon. In 2008 it was 51 cents per gallon, which is equivalent to 75 cents per gallon of gasoline on an energy basis. This subsidy, together with oil in the \$10 to \$30 range, was sufficient to permit steady growth in ethanol production from about 430 million gallons (1625 mil 1.) in 1984 to about 3.4 billion gallons (12.85 bil.1.) in 2004. In

1. Historically, ethanol had almost always been priced considerably higher than gasoline, but in much of 2007/08 ethanol price was lower per gallon than gasoline (http://www.neo.ne.gov/ statshtml/66.html). 
other words, production grew by about 149 million gallons (563 mil.1.) per year over this period. In 2004 , the crude oil price began a steep climb to over $\$ 100 / \mathrm{bbl}$. This rapid increase in the crude price, together with an exogenously fixed ethanol subsidy, led to a tremendous boom in the construction of ethanol plants. As the Renewable Fuels Association (2008) reports, at the beginning of 2000, there were only 54 ethanol plants with a production capacity of 1.7 billion gallons per year (6.4 bil.1). However, by November of 2008, this had expanded to 177 plants with a total capacity of 10.9 billion gallons (41.2 bil.1). Ethanol production in 2007 was about 6.5 billion gallons (24.6 bil.1), and the production capacity could surpass 13 billion gallons (49 bil.1) in 2009. This is not far short of the 15 billion gallons (57 bil.1) of corn-based ethanol mandated under the Energy Independence and Security Act of 2007. It has been the combination of high oil prices, a shift in the demand for ethanol as a fuel additive, and a subsidy that was keyed to \$20 oil that led to this boom in US ethanol production. In the historical analysis below, we will offer a decomposition of the relative contribution of each of these factors in overall ethanol expansion.

EU Policies: The European Union Biofuels Directive requires that member states must realize a $10 \%$ share of biofuels in the liquid fuels market by 2020 (European Commission, 2007). To compare and contrast the EU biofuel directive with the US mandate, we use an estimate for the EU made by the European Commission (2007), which suggests attainment of a $6.25 \%$ share of biofuels in liquid transport fuels by 2015 . This goal is projected to be filled largely by biodiesel. Germany is the largest producer (798 million gallons constituting about $54 \%$ of EU's total biodiesel production in 2006) followed by France (15\%), Italy (9\%), United Kingdom (4\%), Austria (2.5\%), Poland (2.4\%), Czech Republic (2.2\%), Spain (2\%), and others (9\%) (European Biodiesel Board, 2007). The spectacular growth in the German market is the result of very favorable legislation granting a total tax exemption for biofuels. This exemption has been particularly important in the EU, where fuel taxes are extremely high. However, it has recently been rescinded in Germany due to its high budgetary cost, as well as the suspicion that it might be having adverse impacts on land use in the rest of the world. The EU is currently re-evaluating its ambitious biofuels mandates, and a key factor in the deliberations is the global impact - particularly the impact on land use in the tropics. The remainder of this paper seeks to investigate this link between the energy economy, increased biofuel production, agricultural trade and global land use.

\section{METHODOLOGY}

Global Model: Given our goal of evaluating the individual and combined impacts of EU and US biofuel policies on global markets, we need a model that is global in scope, and which links production, consumption and trade, links biofuel demand with petroleum prices and the energy economy in general, links biofuel production to agricultural production and the derived demand for land, and accounts for global competition in agricultural products. All of this has led us to 
develop a special purpose version of the Global Trade Analysis Project (GTAP) model (Hertel, 1997) of the global economy. (See Box 1 for an overview of the GTAP model.) Specifically, we begin with the GTAP-E extension of the core model (Burniaux and Truong, 2002), which has been widely used for analysis of energy and climate change policies. We augment this model by introducing a new parameter, $\sigma$, the constant elasticity of substitution amongst liquid fuel products consumed. This measures the change in the intensity of ethanol use in total liquid fuels in response to a change in the relative price of ethanol: ${ }^{2}$

$$
\sigma=(q e-q) /(p-p e)
$$

This expression can be rearranged to show that the percentage change in demand for ethanol, qe, depends on the change in aggregate demand for liquid fuels, $q$, and on changes in the in the ratio of ethanol prices to changes in the composite price of liquid fuels, $(p e-p)$, pre-multiplied by $\sigma$. A large $\sigma$ results in significant increases in ethanol intensity $(q e-q)$ as the price of ethanol falls, relative to the price of other liquid fuels.

To depict the global competition for land between food and fuel, we augment the GTAP-E model with a land use module, GTAP-AEZ, where AEZ stands for Agro-Ecological Zones (Hertel et al., 2009). This module disaggregates land use into 18 AEZs that share common climate, precipitation and moisture conditions, and thereby capture the potential for competition between alternative land uses. Land supply to specific activities is modeled using the Constant Elasticity of Transformation (CET) revenue function (Powell and Gruen, 1968), which postulates that land owners maximize total returns by allocating their land endowment to different uses, subject to the inherent limitations on land use change:

$$
\begin{aligned}
& \max _{X_{l}} \sum_{l} R_{l} X_{l}=R \\
& \text { s.t. } \quad A=\left[\sum_{l} \theta_{l} X_{l}^{\rho}\right]^{\frac{1}{\rho}}
\end{aligned}
$$

In (2), $R_{l}$ is the market rental rate on land supplied by the land owner to sector $l$. The revenue maximizing allocation of land to $l, X_{l}$, is determined as the solution to (2), with this particular supply accounting for the share of total land rental given by $\theta=R_{l} X_{l} / R$. The constant elasticity of transformation $\tau=(1-\rho)^{-1}$ describes the ease with which land may be shifted between alternative uses. The associated partial equilibrium supply elasticity of land to a given use is given by: $\eta_{l l}=-\left(1-\theta_{l}\right) \tau$ so that the upper bound on the supply elasticity is $-\tau$ and arises

2. A complete development of this model, along with a downloadable version archive is available as a GTAP Technical Paper by Birur, Hertel and Tyner (2007), see also the Technical Appendix to this paper available at: https://www.gtap.agecon.purdue.edu/resources/download/4229.pdf 
when $\theta_{l} \rightarrow 0$. As more land in a given AEZ is diverted to production of the biofuel feedstock (e.g., corn), $\left(\theta_{l} \rightarrow 1\right)$, and the land supply elasticity falls to zero.

We make the assumption of homothetic weak separability in land supplies and divide the allocation problem into two parts. In the first, the landowner allocates land cover across three different types - crop, pasture, and accessible forestry. Conditional on the total availability of land for crop production, the next CET nest determines its allocation across crops. At each stage, the econometrically-based elasticity of transformation differs, as will be seen below. Of course, more complex patterns of nesting are also possible, as evidenced in the work of Eickhout et al. (2008). However, we do not have sufficient econometric information to calibrate a more elaborate pattern of nesting.

When ethanol is produced from corn, Dried Distillers' Grains with Solubles (DDGS) are generated as a by-product, which can be used as a feed ingredient. Sales of DDGS as a livestock feed generate roughly $16 \%$ of total ethanol revenues in the US and displace corn and other feedstuffs. A similar situation arises with biodiesel production from oilseeds. Taheripour et al. (2008) show that ignoring the by-products of biofuels leads researchers to significantly overstate the impact of mandates. They incorporate DDGS and vegetable oil cake (soybean meal in the US and rapeseed cake in EU) and introduce substitution between biofuel by-products and other animal feed in livestock production.

Data Base: In order to address the global impacts of the emerging biofuels industry, we capitalize on several recent data base advances. First of all, we build on the work of Taheripour et al. (2007) which disaggregates three biofuels sectors within the 2001, version 6 GTAP data base. Specifically, these authors break out three new sectors: corn-based ethanol, sugarcane-based ethanol, and oilseed-based biodiesel. They do so by bringing to bear state-of-the-art analyses of the cost structure of these industries, including domestic and imported feedstocks. With the exception of corn-based ethanol, all liquid biofuels are assumed to substitute in final fuel consumption for petroleum products. For corn-based ethanol, we incorporate separately the additive demand for biofuels, as this is less price-responsive. It is treated as an intermediate demand by the petroleum refining industry, the level of which varies directly with total petroleum use. As we will see below, differentiating the price-sensitive and fixed proportions demands for ethanol is critical for our ex post analysis of recent history of the biofuel boom in the US, as well as for our ex ante analysis of future policies.

The global land use data base has four key pieces. The data on land cover are from Ramankutty et al. (2008). These distinguish global land cover by type, including built-up land as well as non-commercial land. For purposes of this study, we only use the forest, pastureland and cropland cover types. Other land uses are assumed to be invariant to biofuels policies. The data base on harvested land cover and yields is from Monfreda et al. (2008a, 2008b). This has its origins in the AgroMaps data base project of FAO, IFPRI and SAGE, which assembled county-level data for all countries of the world and mapped these to 0.5 degree grid cells. These two data bases are aggregated to the $18 \mathrm{AEZ}$ level prior 


\section{Figure 1. Structure of GTAP Model}

The Global Trade Analysis Project (GTAP) model is a multi-commodity, multi-regional computable general equilibrium model documented in a book, published by Cambridge University Press (Hertel ed., 1997) with detailed discussion on theory and derivation of the behavioral equations involved in the model. The standard GTAP model employs the simple, but robust, assumptions of constant returns to scale and perfect competition in all the markets with Walrasian adjustment to ensure a general equilibrium. As represented in the figure below (Brockmeier, 1996), the regional household (e.g., the EU) collects all the income in its region and spends it over three expenditure types - private household (consumer), government, and savings, as governed by a Cobb-Douglas utility function. A representative firm maximizes profits subject to a nested Constant Elasticity of Substitution (CES) production function which combines primary factors and intermediates inputs to produce a final good. Firms pay wages/rental rates to the regional household in return for the employment of land, labor, capital, and natural resources. Firms sell their output to other firms (intermediate inputs), to private households, government, and investment. Since this is a global model, firms also export the tradable commodities and import the intermediate inputs from other regions. These goods are assumed to be differentiated by region, following the Armington assumption, and so the model can track bilateral trade flows.

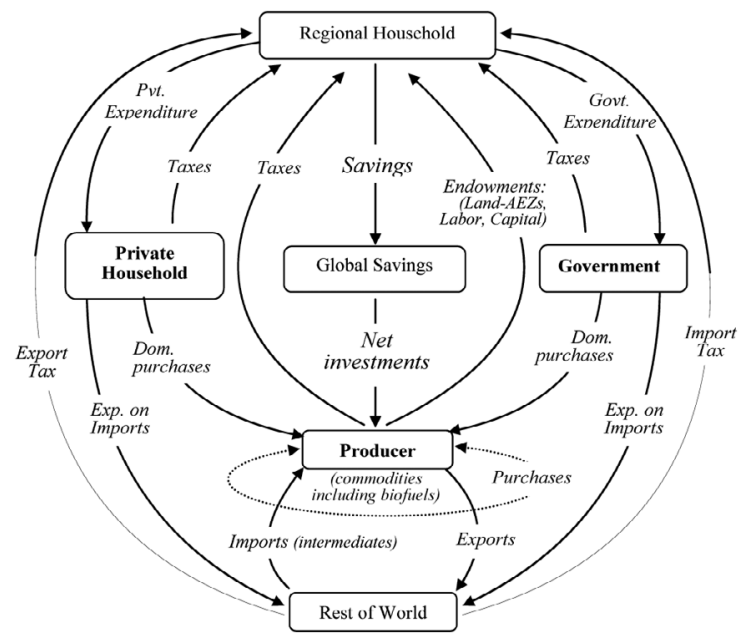

While land is imperfectly mobile (see text), labor and capital are perfectly mobile within a region but immobile across the regions. Government spending is modeled by using a Cobb-Douglas subutility function, which maintains constant expenditure shares across all budget items. The private household consumption is modeled with a non-homothetic Constant Difference of Elasticity (CDE) implicit expenditure function, which allows for differences in price and income elasticities across commodities. Taxes (and subsidies) go as net tax revenues (subsidy expenditures) to the regional household from private household, government, and the firms. The rest of the world gets revenues by exporting to private households, firms and government. In the GTAP model, this rest of world composite is actually made up of many other regions - with the same utility and production functions as for the regional household at the top of this figure.

In this paper, we employ the standard GTAP model closure which imposes equilibrium in all the markets, firms earn zero-profits, the regional household is on its budget constraint, and global investment equals global savings. The global trade balance condition determines the world price of a given commodity. We build on an extended version of the model, GTAP-E, which incorporates the potential for intra-fuel substitution, as well as energy-capital-labor substitution. 
to their incorporation into the GTAP data base. The third land use data base is documented in Sohngen et al. (2009), and maps forestry activity to the forest land cover in the 18 AEZs. Assembling all of these pieces, Lee et al. (2009) produce a GTAP-compatible global land use data base at the AEZ level. This involves disaggregating land rents in the GTAP data base on the basis of prices and yields. This final product is the one used in the present study. Much more discussion of global land use data and associated modeling issues is offered in the forthcoming volume edited by Hertel, Rose and Tol (2009).

Parameters: With the model and data base in place, it remains to discuss the parameters used in this study. As seen above in equation (1), a central parameter in our analysis is the elasticity of substitution between biofuels and petroleum products, $\sigma$. With very limited time series data, reliable estimates of this parameter are not available in the literature. Furthermore, these elasticities are likely to vary greatly by country. For example, the potential for biofuel-petroleum substitution in automobiles depends on the current intensity of biofuels, as well as the stock of flex-fuel vehicles in the national fleet. Accordingly, we utilize historical data to develop general equilibrium estimates of these parameters over the 2001-2006 period.

From the perspective of supply response and land use, the key parameters in the model are those which govern the responsiveness of land use to changes in relative returns. As seen in (2) above, the negative of the transformation elasticities $(\tau)$ in the CET function represents the upper bound supply elasticity of the factor (in response to a change in factor returns). For land cover, we draw on Lubowski, Plantinga, and Stavins (2006), who report land use elasticities consistent with a 5 year land cover transformation parameter of -0.11 and a 10 year value of -0.22 (Ahmed, Hertel and Lubowski, 2009). In this paper, we set this value to -0.20 . A transformation parameter of -0.5 for the crop frontier is obtained by taking the maximum acreage response elasticity from the FAPRI model documentation (FAPRI, 2004) for corn acreage response across the different regions of the United States.

The issue of an endogenous yield response to biofuels policy changes has been quite controversial. One article that has drawn attention to the land use impacts of biofuel policies is that of Searchinger et al. (2008) who assume that there is no change in baseline yields as a consequence of biofuels policies. This has proven quite controversial - particularly in light of their finding that US biofuels programs are likely to result in very substantial indirect land use impacts in the rest of the world. Some biofuels advocates have argued the other extreme - namely that increased yields can accommodate all of the incremental feedstock demands. This is an area where a great deal of economic research has been undertaken - particularly for corn. Keeney and Hertel (2008) explore this issue in detail, and here we adopt their central case assumption of a long run yield response to output price changes (relative to variable input prices) of 0.4 . We follow those authors in calibrating to this parameter by adjusting the elasticity of substitution in crop production to hit this targeted yield response. 
As Searchinger and Heimlich (2007) have identified, the bilateral pattern of trade is also important in determining the global impacts of biofuels policies. Countries with a close trading relationship with the US, for example, are more likely to be affected by such policies. Those authors focused solely on US exports of oilseeds, and assumed that reductions in exports would be offset by increases in domestic production in the destination countries. However, in reality, the global trading system is much more complex. First of all, the US is both an exporter and an importer of oilseeds. Secondly, these bilateral patterns of trade are price sensitive, and therefore endogenous to any biofuels policies. As US exports to the Middle East become more expensive, for example, competitors will seek to erode the US market share. This means that the land use impact may well crop up in third markets with which the US may not even trade directly. This price responsiveness of bilateral trade is governed by the "Armington" elasticity of substitution among imports. We draw on recent econometric estimates of Hertel et al., (2007), who utilize variation in bilateral trade costs in order to estimate the elasticity of substitution amongst products supplied by different exporters. Those authors estimate this elasticity for corn (coarse grains) to be 2.6 with a standard error of 1.1 , and 4.9 (0.8) for oilseeds (Hertel et al., 2007, Table 1).

The final set of parameters which deserve our attention relate to the price elasticity of demand for petroleum products. Following the stochastic simulation approach of Valenzuela et al. (2007), Beckman (2008) seeks to validate the GTAPE model with respect to the petroleum product market. He finds that demand is far too elastic in GTAP-E. This is in confirmation with Espey (1998) who conducted a meta-analysis based on over 300 estimates from the literature. Her study suggests that the median price elasticity of demand for petroleum is -0.23 with a range of 0 to -1.36 , and averaging -0.26 . Also, Beckman (2008) notes that the elasticity of substitution amongst energy sources was too elastic in GTAP-E - a result key to our analysis. With these issues in mind, Beckman (2008) offers a revised set of GTAP-E parameters, which is what we use for this study.

The model is implemented using GEMPACK (Harrison and Pearson, 1994), and we make special use of the decomposition feature developed by Harrison, Horridge and Pearson (2000) which exploits numerical integration techniques in order to exactly separate the impacts of different policy shocks on endogenous variables of interest.

\section{HISTORICAL ANALYSIS}

We begin by validating the model against recent history. Since this is a global general equilibrium model, there are many different variables upon which we could focus our attention. However, we believe the most important of these is the share of total liquid fuels provided by biofuels. Indeed many of the biofuel mandates are expressed in terms of such a share, so being able to track this over the 2001-2006 period is quite important. Table 1 reports changes in total liquid fuel consumption in the US and the EU. 
Table 1. The Changing Structure of the Biofuel Economy

\begin{tabular}{|c|c|c|c|c|c|c|c|}
\hline \multirow[b]{2}{*}{ Fuel Consumption: } & \multirow[b]{2}{*}{ Units } & \multicolumn{3}{|c|}{ US } & \multicolumn{3}{|c|}{ EU-27 } \\
\hline & & 2001 & 2006 & 2015 & 2001 & 2006 & 2015 \\
\hline \multicolumn{8}{|l|}{ Liquid fuels for Transport: } \\
\hline Petroleum & Q. Btu & 25.96 & 27.57 & 29.63 & 18.20 & 18.20 & 18.50 \\
\hline Total Biofuels ${ }^{\mathrm{a}}$ & Q. Btu & 0.150 & 0.503 & 1.508 & 0.037 & 0.224 & 1.156 \\
\hline Ethanol & Q. Btu & 0.149 & 0.471 & 1.341 & - & 0.035 & 0.183 \\
\hline Biodiesel & Q. Btu & 0.001 & 0.032 & 0.167 & 0.037 & 0.189 & 0.973 \\
\hline $\begin{array}{l}\text { Share of biofuels in liquids } \\
\text { for transport (energy basis) }\end{array}$ & $\%$ & 0.58 & 1.83 & 5.09 & 0.20 & 1.23 & 6.25 \\
\hline \multicolumn{8}{|l|}{ Biofuel Policies: } \\
\hline Subsidy for Ethanol & $\$ /$ gall & 0.51 & 0.51 & & - & 1.00 & \\
\hline Average Price of Ethanol ${ }^{b}$ & $\$ /$ gall & 1.48 & 2.58 & & 1.48 & 1.96 & \\
\hline Ad valorem equivalent of subsidy & 1.34 & 1.20 & & 1.00 & 1.51 & & \\
\hline$\%$ ch in subsidy (2001-2006) & & -10.9 & & & 51.0 & & \\
\hline Subsidy for Biodiesel ${ }^{c}$ & $\$ /$ gall & 1.00 & 1.00 & & - & 1.90 & \\
\hline Average Price of Biodiesel ${ }^{\mathrm{d}}$ & $\$ /$ gall & 2.45 & 3.23 & & 2.33 & 2.34 & \\
\hline Ad valorem equivalent of subsidy & & 1.41 & 1.31 & & 1.00 & 1.81 & \\
\hline$\%$ ch in subsidy (2001-2006) & & & -7.0 & & & 81.2 & \\
\hline
\end{tabular}

Note: aiofuels include both domestic production and imports of ethanol and biodiesel

bEthanol prices for EU-27 corresponds to France

${ }^{c}$ Subsidies in the US and Tax Credits in the EU-27

${ }^{d}$ Biodiesel prices for EU-27 corresponds to Germany

Data Source: Projected data is from Energy Information Administration, U.S. Department of Energy.

It can be seen from the table that the US share tripled from 2001 to 2006, rising from less than $0.6 \%$ to more than $1.8 \%$. Most of this was in the form of domestically produced, corn-based ethanol, but a seventh of the total came in the form of imports of sugarcane-based ethanol; finally, a very small amount came from biodiesel. In the EU, the share of biofuels in total liquid fuel consumption rose more than six-fold over this period, from $0.2 \%$ to $1.23 \%$, with the majority being delivered as biodiesel.

Partial Equilibrium Analysis: The major drivers of this growth in biofuels have been: petroleum prices, biofuel subsidies, and the ban on competing fuel additives in the US. While our empirical analysis of the biofuel boom is conducted in global, general equilibrium, it is instructive to begin with a simple, partial equilibrium model for biofuels which highlights the role of each of these three drivers of change. Such a model is developed in the Technical Appendix (footnote 2). It assumes that the price of composite liquid fuels for transport is exogenous, total demand for liquid fuels is fixed, and there are two types of ethanol demand - one which is not responsive to price (i.e. ethanol for oxygenation) and one which is an energy substitute and therefore is price responsive. In the absence of ethanol trade, we can then solve for the equilibrium percentage change in ethanol output, $q o^{*}$, as follows: 


$$
q o^{*}=\varepsilon_{s}\left[(1-\alpha) a i-\varepsilon_{D}(p+s)\right] /\left[\varepsilon_{s}-\varepsilon_{D}\right]
$$

Here the key drivers of ethanol output change are: $a i$, the percentage change in the input-output ratio prescribing additive use in gasoline (this will rise when alternative oxygenators are banned), $p$, the percentage change in the price of composite liquid fuels, and $s$, the percentage change in the power of the ad valorem-equivalent subsidy on ethanol production (i.e. $s$ is one plus the subsidy rate). The parameters in this equation are as follows: $\varepsilon_{D}=-\alpha \sigma$ is the composite price elasticity of demand for ethanol (the product of the share of ethanol going to the price-sensitive (energy-substitution) side of the market, $\alpha$, and the elasticity of substitution in use between ethanol, biodiesel and petroleum, $\sigma$ ); $\varepsilon_{S}=v_{C} \theta_{C}^{-1}$ is the price elasticity of supply for ethanol which is determined by the product of the own-price elasticity of supply of corn, $v_{C}$, and the inverse of the share of costs of corn in ethanol production, $\theta_{C}^{-1}$.

From (3), we can obtain some useful insights into the impact of these drivers on the growth in biofuels output. First of all, the contribution of changes in the additive requirements of gasoline to total ethanol output depend on the change in the input-output ratio, $a i$, as well as the initial share of total sales going to this market segment. The price sensitive portion of the market depends on what happens to the price of energy in general, $p$, and the power of the subsidy, $s$. When the change in the latter is expressed as the change in the power of the ad valorem subsidy equivalent (as is the case here), these two effects are additive. Their combined significance depends on the share of the total market for ethanol that is price sensitive $(\alpha)$ and the ease of substitution between ethanol and other fuels $(\alpha)$. Furthermore, we see from (3) that feedstock supply response is also important. If the total availability of feedstock (corn) is fixed $\left(v_{C}\right)$, then $q o^{*}=0$. Furthermore, as $v_{C}$ rises and the share of corn in overall ethanol costs falls $\left(\theta_{C} \rightarrow 0\right), v_{C} \theta_{C}^{-1}=\varepsilon_{S}$ rises, thereby boosting supply.

From a validation point of view, note that, given estimates of the other parameters and shocks in equation (3), we could choose $\sigma$ to replicate the historically observed value of qo, or some derivative thereof, e.g., the renewable fuel share. By evaluating the plausibility of these estimates of $\sigma$, we obtain some further validation of the model.

Equation (3) is critical when it comes to decomposing the contribution of the three main drivers of biofuel production over the 2001-2006 period. The main drivers of the biofuel boom during 2001-2006 as offered by Birur, Hertel, Tyner (2007) are: increase in crude oil price by $136 \%$ (from $\$ 25$ a barrel to $\$ 60$ ), increase in additive demand for ethanol in the US by $49 \%$, a subsidy of $\$ 0.51$ per gallon of ethanol and \$1 per gallon of biodiesel in the US, and tax credit of \$1 per gallon of ethanol and \$1.9 per gallon of biodiesel in the EU.

General Equilibrium Analysis: We first simulate the general equilibrium model over the 2001-2006 period. One approach to this would be to shock all the exogenous variables in the model by the observed values over this period, then compare the endogenous variables to their observed values by way of model vali- 
dation. However, the vast majority of exogenous variables are either unobserved (technological change) or unavailable on a global, time series basis for the period in question (bilateral trade policies, domestic taxes and subsidies). We are therefore forced to adopt a more modest approach to our historical simulation. Instead of shocking all the exogenous variables in the economy, we shock only those key drivers that shape the EU and US biofuel economy over this period - namely the price of petroleum, biofuel policies in the US and the EU, and the ethanol additive requirements in the US (recall equation 3). In this way, we seek to impose the 2006 biofuel economy on the observed 2001 global economy. In doing so, we greatly reduce the information requirements for this historical analysis, thereby sharpening our focus on the issue at hand - namely the impact of changing the way liquid fuel is delivered to the global economy.

The estimated elasticity of substitution between biofuels and petroleum products $(\sigma)$ is a key parameter. Its default value is 2.0 (Birur, Hertel, and Tyner 2007). In the cases of Brazil, USA and EU, we have sufficient information to alter this default value. Specifically, we estimate it using the non-linear form of equation (1), within the context of the full CGE model, in order to hit the observed renewable fuel share target reported in Table 1 (recall the discussion above). The resulting estimates of $\sigma$ are: Brazil $=1.35, \mathrm{EU}=1.65$ and $\mathrm{USA}=3.95$. The relatively low elasticity in Brazil reflects the fact that ethanol already commands a large share of that market, and large percentage changes become more difficult as ethanol becomes more dominant. The estimated elasticity of substitution in the US is high, relative to Europe, particularly in light of the fact that the EU renewable fuel share grew by a much larger percentage over this period. However, the latter growth is well-explained by the significant subsidies implicit in the fuel tax exemptions in France and Germany. In addition, in the base period (2001), the share of US ethanol going to the price inelastic additive market was quite high (about $75 \%$ ). This requires the elasticity of substitution in the price-sensitive part of the market to be higher. Finally, the economic "power" of the US ethanol subsidy diminished as the prices of gasoline and ethanol rose (See the lower panel of Table 1 wherein the ad valorem equivalent in the US falls by $10.9 \%$ ). For all these reasons, a large elasticity of substitution is required to explain the growth in the renewable fuel share in the US.

Given these estimates of the elasticity of substitution between biofuels and other energy products, we can also decompose the impact of the main drivers of renewable fuel output growth in the EU and US markets. Table 2 provides the general equilibrium analogue to the decomposition of equilibrium output growth given in equation (3). In the top panel we have a decomposition of US output growth, due to the exogenously dictated change in renewable fuel share over the 2001-2006 period. Of the total change in ethanol growth (133.5\%) driven by this compositional change in liquid fuels, $64 \%$ of the total figure is attributed to the MTBE ban, $93 \%$ is attributed to the rise in petroleum prices, $-23 \%$ is due to the diminishing relative importance of the $\$ .51 /$ gallon blenders' subsidy, and a negligible amount in US output growth is attributed to the growth in EU subsidies. 
Table 2. Decomposition of the Drivers behind the Biofuels Boom: 2001-2006

\begin{tabular}{lccccc}
\hline \multicolumn{7}{c}{ Percent Change in Output by Sector } \\
\hline Total & \multicolumn{5}{c}{ Decomposed by Driver } \\
US & Change & Additives & Oil Price & Subsidy-US & Subsidy-EU \\
\hline Ethanol & 133.5 & 64.0 & 93.1 & -22.7 & 0.0 \\
Coarse Grains & 3.0 & 1.5 & 1.9 & -0.6 & 0.1 \\
Other Grains & -1.9 & -0.7 & -1.4 & 0.2 & 0.0 \\
Oilseeds & 1.4 & -0.4 & 0.9 & 0.1 & 0.6 \\
Sugarcane & -0.5 & -0.1 & -0.4 & 0.0 & 0.0 \\
Other Agri & -0.5 & -0.1 & -0.4 & 0.0 & 0.0 \\
Livestock & -0.8 & -0.1 & -0.7 & 0.0 & 0.0 \\
Forestry & -0.1 & -0.1 & -0.1 & 0.0 & 0.0 \\
\hline & Total & & Decomposed by Driver & \\
EU-27 & Change & Additives & Oil Price & Subsidy-US & Subsidy-EU \\
\hline Biodiesel & 341.4 & -0.3 & 140.3 & 0.1 & 201.7 \\
Coarse Grains & -1.6 & 0.0 & -1.2 & 0.0 & -0.4 \\
Other Grains & -1.2 & 0.0 & -0.5 & 0.0 & -0.8 \\
Oilseeds & 14.2 & 0.1 & 5.7 & -0.1 & 8.2 \\
Sugarcane & -0.4 & 0.0 & -0.3 & 0.0 & -0.2 \\
Other Agri & -0.2 & 0.0 & -0.1 & 0.0 & -0.2 \\
Livestock & -0.6 & 0.0 & -0.5 & 0.0 & -0.1 \\
Forestry & -0.8 & 0.0 & -0.4 & 0.0 & -0.3 \\
\hline
\end{tabular}

The predicted changes in US agricultural and forestry output, due to these changes in the fuel economy, are reported in the subsequent rows of Table 2. Coarse grains output is estimated to have been about $3 \%$ higher in 2006 , solely due to the increase in renewable fuel use. The majority of this (1.9\% output growth) was driven by higher oil prices, with the next largest portion (1.5\%) being driven by the MTBE ban. With the exception of oilseeds, these changes in the global fuel economy led to declines in the output of other agricultural and forestry activities, as land was diverted to corn production. However, oilseed production shows a positive gain due to changes in the global fuel economy - primarily due to the boom in EU biodiesel production.

The lower panel of Table 2 reports comparable results for the EU, beginning with biodiesel output - the primary renewable fuel in the EU. Here, the percentage increase is much larger - more than $341 \%$ ! This is driven primarily by the combination of fuel tax exemptions (202\%). (The ad valorem equivalent of the power of the EU subsidy on biodiesel rose by $81.2 \%$ over this period.) This is followed by the contribution of higher oil prices (140\%). These are also the main drivers behind the associated changes in EU agricultural and forestry output reported in the bottom panel of Table 2 . The predicted rise in oilseeds output in the $\mathrm{EU}$ in the wake of this change in the fuel economy is $14 \%$ - driven mainly by increased EU subsidies, followed by higher oil prices. 
Table 3 reports the disposition of key biofuel feedstocks in 2001 and 2006 in Brazil, EU and the US. (Bear in mind that these shares abstract from other developments in the global economy, including changes in EU and US farm programs, China's growing demand for Brazilian soybeans, etc.). As seen from Table 3 , the model predicts that the share of US coarse grains (corn) going to ethanol production over this period increased from $5.6 \%$ in 2001 to about $13 \%$ in 2006. This matches the historical experience in the US quite closely. This eight percentage point increase in the share of coarse grains sold for ethanol has come from reduction in other sectors, including such as feed industry ( -6 percentage points), exports (-1 percentage point) and other industries (less than -1 percentage point). Similarly, in the case of the EU, the share of oilseeds going to the biodiesel sector has increased from $5 \%$ to $20 \%$ during the $2001-06$ period, which again comes from a large reduction in use of oilseeds in food products and other sectors. The EU also produces a small amount of grain based bio-ethanol, and the model predicts a small increase in the share of coarse grains going to the ethanol sector. The final panel in Table 3 reports the results for Brazil, where there is a modest increase in the share of sugarcane going into the production of ethanol from 2001-2006. The model also predicts a sharp rise in ethanol exports which has indeed been observed.

Table 3. Disposition of Feedstock in the Changing Global Biofuel Economy

\begin{tabular}{|c|c|c|c|c|c|c|c|}
\hline \multirow[t]{3}{*}{ US } & & & & \multicolumn{4}{|l|}{ EU-27 } \\
\hline & Base & Base & Mandates & & Base & Base & Mandates \\
\hline & 2001 & 2006 & 2015 & & 2001 & 2006 & 2015 \\
\hline \multicolumn{4}{|c|}{ Disposition of Coarse grains (\%) } & \multicolumn{4}{|c|}{ Disposition of Oilseeds (\%) } \\
\hline Ethanol1 & 5.6 & 13.1 & 33.5 & Biodiesel & 5.2 & 19.8 & 68.5 \\
\hline Feed & 48.2 & 42.0 & 28.9 & Food products & 51.6 & 43.8 & 18.3 \\
\hline Other & 18.6 & 18.4 & 16.3 & Other & 23.9 & 20.0 & 8.8 \\
\hline \multirow[t]{4}{*}{ Exports } & 27.6 & 26.5 & 21.3 & Exports & 19.3 & 16.4 & 4.4 \\
\hline & & & & \multicolumn{4}{|c|}{ Disposition of Coarse Grains (\%) } \\
\hline & & & & Ethanol-1 & 0.6 & 2.0 & 13.2 \\
\hline & & & & Feed & 51.0 & 48.9 & 36.5 \\
\hline \multicolumn{8}{|l|}{ Brazil } \\
\hline & Base & Base & Mandates & & Base & Base & Mandates \\
\hline & 2001 & 2006 & 2015 & & 2001 & 2006 & 2015 \\
\hline \multicolumn{4}{|c|}{ Disposition of Sugarcane (\%) } & \multicolumn{4}{|c|}{ Disposition of Ethanol-2 (\%) } \\
\hline Ethanol2 & $43.5^{\circ}$ & 60.8 & 70.8 & Domestic & 97.4 & 62.1 & 33.9 \\
\hline Sugar & 44.3 & 28.6 & 19.4 & Exports & 2.6 & 37.9 & 66.1 \\
\hline Other & 12.1 & 10.6 & 9.8 & & & & \\
\hline
\end{tabular}

Note: Ethanollrefers to the corn based ethanol and ethanol2 is the sugarcane based ethanol.

The final set of results pertaining to this historical analysis is related to land use changes. The first panel in Table 4 reports the predicted changes in land use over this historical period. The model predicts strong increases in US coarse grains and EU oilseed production, as well as a sharp rise in sugarcane production in Brazil. 
Table 4. Change in Land Use due to US-EU Biofuel Programs

\begin{tabular}{lcccccc}
\hline Land-related sectors: & US & $\begin{array}{c}\mathbf{2 0 0 1 - 2 0 0 6} \\
\text { EU-27 }\end{array}$ & Brazil & US & $\begin{array}{c}\mathbf{2 0 0 6 - 2 0 1 5} \\
\text { EU-27 }\end{array}$ & Brazil \\
\hline Land use change (\%): & & & & & & \\
$\quad$ Coarse Grains & 2.3 & -1.7 & -2.2 & 6.2 & -9.0 & -10.5 \\
$\quad$ Oilseeds & 0.8 & 12.9 & -2.1 & 7.7 & 47.8 & 6.4 \\
$\quad$ Sugarcane & -0.8 & -0.7 & 24.3 & -4.2 & -6.6 & 22.9 \\
Other Grains & -1.8 & -1.4 & -2.6 & -7.4 & -15.0 & -18.0 \\
$\quad$ Other Agri & -0.6 & -0.4 & -3.4 & -1.8 & -5.4 & -10.6 \\
\hline Land cover change (\%) & & & & & & \\
$\quad$ Crops & 0.1 & 0.3 & 1.3 & 0.7 & 2.1 & 2.8 \\
Forest & -0.3 & -0.8 & -3.4 & -2.5 & -8.2 & -9.2 \\
Pasture & -0.7 & -0.9 & -2.6 & -3.8 & -9.4 & -9.7 \\
\hline
\end{tabular}

Obviously the fuel price rise, the MTBE ban, and the US and EU subsidy adjustments are not the only things going on over the 2001-2006 period. However, it is instructive to compare the results to the actual changes in these key feedstock land areas over this period. In reality, US corn area was up by $3.5 \%$ (vs. $2.3 \%$ in our simulation), EU oilseed area rose by more than $30 \%$ (vs. 13\% in Table 4), and Brazilian sugarcane area rose by about $20 \%$ (vs. $24 \%$ in our historical simulation). Overall, we estimate that, if no other changes had occurred over the 2001-2006 period, the change in composition of the fuel economy would have boosted crop land cover in US, EU and Brazil by roughly $0.1 \%, 0.3 \%$ and $1.3 \%$, respectively.

\section{EX ANTE ANALYSIS OF EU AND US BIOFUEL PROGRAMS}

We now turn to a forward-looking analysis of EU and US biofuel programs. The US Energy Independence and Security Act of 2007 calls for 15 billion gallons of corn ethanol use by 2015 , which amounts to about $5.1 \%$ of project liquid fuels consumption in 2015 on an energy basis. In the EU, the target is $5.75 \%$ of renewable fuel use in 2010 and $10 \%$ by 2020 . However, there are significant doubts as to whether these goals are attainable. For this analysis, we adopt the conservative mandate of $6.25 \%$ by 2015 in the EU. The starting point for our prospective simulations is the updated 2006 fuel economy which results from the foregoing historical analysis. Thus, we analyze the impact of a continued intensification of the use of biofuels in the economy - this time treating the mandates as exogenous shocks. ${ }^{3}$

Impact on Output: Table 5 reports the percentage changes in output for biofuels and the land-using sectors in the USA, EU and Brazil. The first column in each block corresponds to the combined impact of EU and US policies on a given sector's volume of output (USEU-2015). The second column in each block

3. Technically, we endogenize the subsidy on biofuel use and exogenize the renewable fuel share, and then shock the latter. For simplicity, all components of the renewable fuels bundle are assumed to grow in the same proportion. 
reports the component of this which is attributable to the US policies (US-2015), and the third reports the component of the total due to the EU policies (EU-2015) using the decomposition technique of Harrison, Horridge and Pearson (2000). This decomposition approach is a more sophisticated approach to the idea of first simulating the global impacts of a US program, then simulating the impact of an EU biofuels program, and finally, simulating the impact of the two combined. The problem with that (rather intuitive) approach is that the impacts of the individual programs will not sum to the total, due to interactions. By adopting this numerical integration approach to decomposition, the combined impacts of the two programs are fully attributed to each one individually.

In the case of the US impacts (columns labeled Outputs in US) coarse grains output rises by nearly $11 \%$ and oilseeds by $13 \%$, while outputs of other crops and livestock fall in the combined USEU simulation. When only US policies are considered, results are quite similar, excepting for oilseeds. Here, the production impact of EU mandates is dominant. In order to meet the $6.25 \%$ renewable fuel share target, the EU requires a massive amount of oilseeds. Even though production in the EU rises by $59 \%$ additional imports of oilseeds and vegetable oils are required, and this serves to stimulate production worldwide, including in the US. Thus, while US oilseeds output increases by just $2 \%$ in the presence of US-only programs, due to the dominance of ethanol in the US biofuel mix, when the EU policies are added to the mix, US oilseed production rises by more than coarse grains in percentage terms.

\section{Table 5. Change in Output due to EU and US Biofuel Mandates: 2006-2015}

\begin{tabular}{lccccccccc}
\hline Sectors: & \multicolumn{3}{c}{ Outputs in US (\%) } & \multicolumn{3}{c}{ Outputs in EU (\%) } & \multicolumn{3}{c}{ Outputs in Brazil (\%) } \\
& USEU- & US- & EU- & USEU- & US- & EU- & USEU- & US- & EU- \\
& 2015 & 2015 & 2015 & 2015 & 2015 & 2015 & 2015 & 2015 & 2015 \\
\hline Ethanol & $184.0^{*}$ & 183.8 & 0.2 & $515.4^{*}$ & 1.2 & 514.2 & $62.4^{*}$ & 64.6 & -2.2 \\
Biodiesel & $1964^{*}$ & 1963 & 1.2 & $530.6^{*}$ & 1.7 & 528.9 & - & - & - \\
Coarse Grains & $10.7^{*}$ & 9.4 & 1.4 & $-5.7^{*}$ & 0.3 & -6.1 & $-7.6^{*}$ & -6.0 & -1.6 \\
Oilseeds & $13.1^{*}$ & 2.0 & 11.1 & $58.9^{*}$ & 2.4 & 56.5 & $11.1^{*}$ & -9.2 & 20.3 \\
Sugarcane & $-0.9^{*}$ & -0.9 & 0.0 & $-3.3^{*}$ & 0.0 & -3.3 & $33.9^{*}$ & 35.8 & -2.0 \\
Other Grains & $-5.2^{*}$ & -5.1 & -0.1 & $-12.4^{*}$ & -0.3 & -12.1 & $-15.9^{*}$ & -11.1 & -4.8 \\
Other Agri & $-0.9 *$ & -0.9 & 0.0 & $-3.9^{*}$ & 0.0 & -4.0 & $-9.1^{*}$ & -7.3 & -1.8 \\
Livestock & -0.6 & -0.6 & -0.1 & $-1.4^{*}$ & 0.1 & -1.5 & $-3.3^{*}$ & -2.9 & -0.5 \\
Forestry & -0.8 & -0.8 & 0.0 & $-5.2^{*}$ & -0.3 & -4.9 & $-6.0^{*}$ & -4.8 & -1.2 \\
\hline
\end{tabular}

Note: Ethanol in the US and EU is produced from grains, and it is sugarcane-based in Brazil.

* indicates that mean values are larger than twice the standard deviations from zero, reflecting significant variation in results subjected to the given range of parameter values. Sensitivity results are not reported for separate US and EU policies. 
In the case of the EU production impacts (Outputs in EU: the second group of columns in Table 5), the rise in oilseed production dominates, with production of other crops and livestock declining as resources are diverted to feedstocks for the biodiesel sector. In the EU, the impact of US policies is quite modest, with the main interaction again through the oilseeds market. However, when it comes to third markets - in particular Brazil (Outputs in Brazil), the US and EU both have important impacts. US policies drive sugarcane production, through the ethanol sector, so that sugarcane output in Brazil rises by about one-third. On the other hand, EU policies drive oilseeds production in Brazil, which rises by $11 \%$ in the full US-EU scenario. Due to the aggregate constraint on land, other crops, livestock, and forestry are forced to contract in the wake of expansion in the biofuel feedstock sectors.

Impact on Trade: In order to better understand the impacts of US and EU policies on Brazil, and other third markets, we turn to Table 6, which reports the change in bilateral trade volumes for coarse grains, oilseeds and other food products as a result of the combined mandates. As can be seen from the first row of entries, US exports of coarse grains are reduced by $\$ 658$ million at constant prices. Of course, this prediction is made, holding all other changes in the world economy constant. In practice, rising demand in the rest of the world, due to factors not considered here, such as rising population and incomes, could counteract the impact of biofuel mandates on US exports.

Turning to the EU, exports of coarse grains, oilseeds and other food products are sharply reduced across the board. Other regions increase their exports to both the US and the EU, with the largest volume changes arising in the case of oilseed exports to the EU. Here, the leader is Brazil, followed by the US, other countries in the Americas and Eastern Europe, re-exports from Hong Kong, India, and Africa. In short, the EU draws on additional oilseeds from around the globe, thereby stimulating the demand for additional crop land overseas.

Impact on Land Use and Land Cover: Table 7 reports changes in crop harvested area owing to the biofuel mandates in the US and EU for all regions in the model while figures A1-A2 in the Technical Appendix (footnote 2) show the percentage change in land area under coarse grains and oilseeds, by AEZ and region, following the US and EU biofuel mandates for 2015. The percentage change in acreage varies considerably across AEZs, for instance in the US, the largest percentage changes in corn acreage (up to 13\%) are in the less-productive AEZs which contribute little to national coarse grains output while the smallest changes $(5 \%)$ are in the corn belt, resulting in a productivity-weighted rise in coarse grains acreage of $6 \%$ (Table 7). This increase in corn acreage in the US comes from contribution of land from other land-using sectors such as other grains (Table 7) as well as pasture land and commercial forest land - to which we will turn momentarily. 


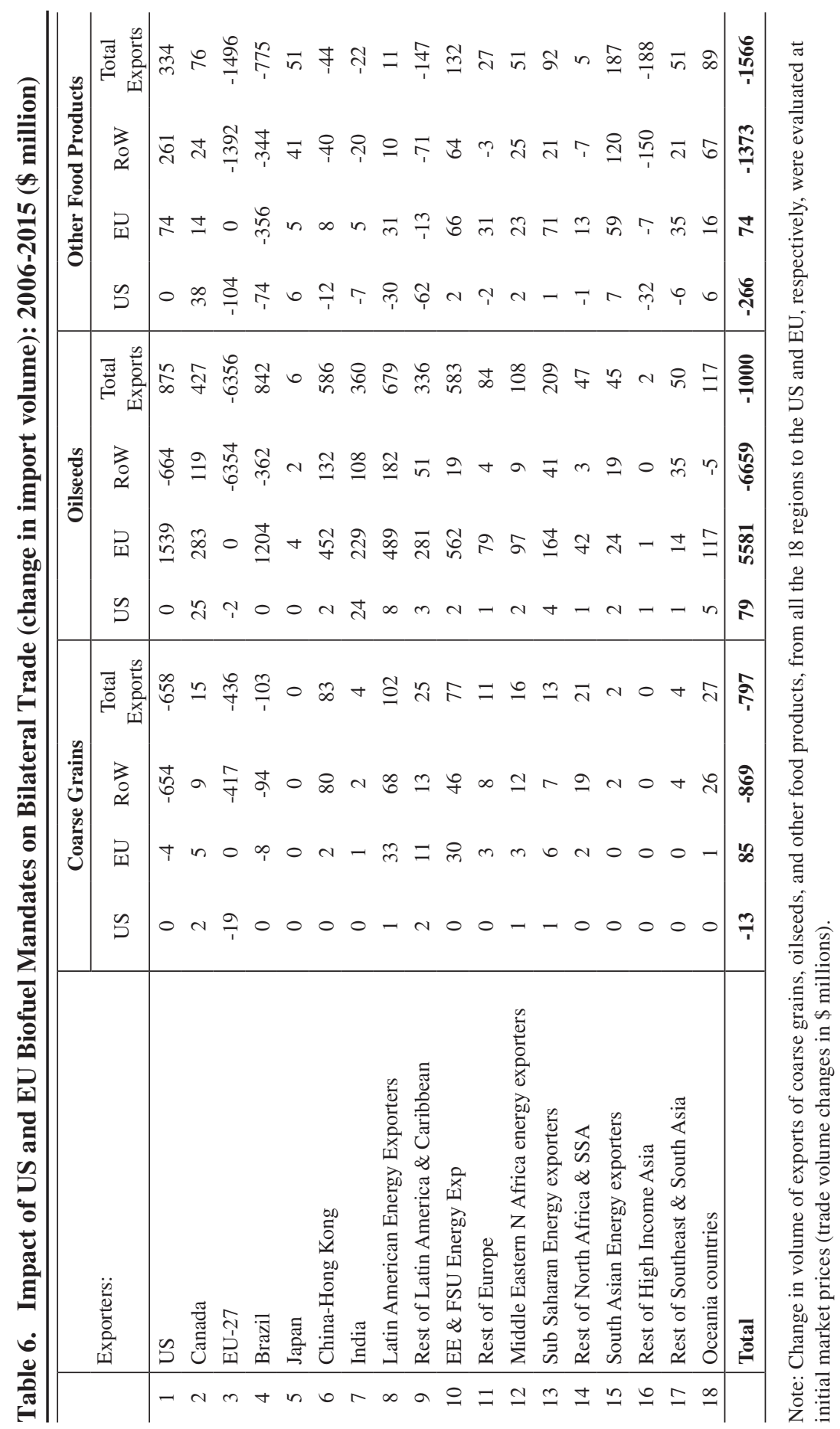


Table 7. Change in Crop Harvested Area by Region, due to EU and US Biofuel Mandates

\begin{tabular}{lccccc}
\hline & \multicolumn{2}{c}{$\%$ Change in Crops - 2006-2015 } & \\
Region: & $\begin{array}{c}\text { Coarse } \\
\text { Grains }\end{array}$ & Oilseeds & $\begin{array}{c}\text { Sugar- } \\
\text { cane }\end{array}$ & $\begin{array}{c}\text { Other } \\
\text { Grains }\end{array}$ & $\begin{array}{c}\text { Other } \\
\text { Agri }\end{array}$ \\
\hline U.S.A. & $6.2^{*}$ & $7.7^{*}$ & $-4.2^{*}$ & $-7.4^{*}$ & $-1.8^{*}$ \\
\hline Canada & -0.6 & $19.4^{*}$ & $-3.0^{*}$ & $-2.5^{*}$ & $-1.5^{*}$ \\
\hline EU-27 & $-9.0^{*}$ & $47.8^{*}$ & $-6.6^{*}$ & $-15.0^{*}$ & $-5.4^{*}$ \\
\hline Brazil & $-10.5^{*}$ & $6.4^{*}$ & $22.9^{*}$ & $-18.0^{*}$ & $-10.6^{*}$ \\
\hline Japan & $5.2^{*}$ & $7.6^{*}$ & -0.5 & 0.6 & -0.1 \\
\hline China-Hong Kong & 0.8 & $6.7^{*}$ & -0.5 & -0.2 & -0.4 \\
\hline India & -0.6 & 0.9 & -0.6 & 0.3 & -0.2 \\
\hline Latin American Energy Exporters & 0.4 & $12.2^{*}$ & $-1.9^{*}$ & 0.2 & -0.6 \\
\hline Rest of Latin America \& Caribbean & -0.1 & $12.3^{*}$ & $-1.5^{*}$ & -0.7 & -0.3 \\
\hline EE \& FSU Energy Exp & 0.3 & $18.8^{*}$ & -0.5 & 0.0 & -0.3 \\
\hline Rest of Europe & 0.8 & $11.2^{*}$ & 0.1 & 1.8 & 0.5 \\
\hline Middle Eastern North Africa & $2.1^{*}$ & $9.0^{*}$ & -0.4 & $2.4^{*}$ & -0.3 \\
\hline energy exporters & $-1.0^{*}$ & $14.1^{*}$ & -0.1 & $2.2^{*}$ & 1.1 \\
\hline Sub Saharan Energy exporters & 0.1 & $15.7^{*}$ & -0.2 & 1.3 & $1.3^{*}$ \\
\hline Rest of North Africa \& SSA & -0.7 & $2.6^{*}$ & $-0.8^{*}$ & -0.5 & 0.0 \\
\hline South Asian Energy exporters & $2.3^{*}$ & $6.0^{*}$ & -0.2 & -0.2 & 0.0 \\
\hline Rest of High Income Asia & -0.4 & $2.7^{*}$ & $-0.7^{*}$ & -0.1 & -0.1 \\
\hline Rest of Southeast \& South Asia & 1.4 & $19.3^{*}$ & -0.4 & $-1.3^{*}$ & 0.4 \\
\hline Oceania countries & & & & & \\
\hline
\end{tabular}

Note: * indicates that mean values are larger than twice the standard deviations from zero, reflecting significant variation in results subjected to the given range of parameter values.

From Table 7, we see that US oilseeds acreage is up by $7.7 \%$ mainly due to the influence of EU policies on the global oilseeds market. However, this increase is dwarfed by the increased acreage devoted to oilseeds in other regions, where the percentage increases range from $6-12 \%$ in Latin America, and 15\% in Africa, to nearly $20 \%$ in Canada and $48 \%$ in the EU. If the EU really intends to implement its 2015 renewable fuels target, there will surely be a global boom in oilseeds. Coarse grains acreage in most other regions is also up, but by much smaller percentages. Clearly the US-led ethanol boom is not as significant a factor as the EU oilseeds boom. Sugarcane area rises by $23 \%$ in Brazil, but declines elsewhere, and other grains and crops are somewhat of a mixed bag, with acreage rising in some regions to make up for diminished production in the US and EU and declines elsewhere. 


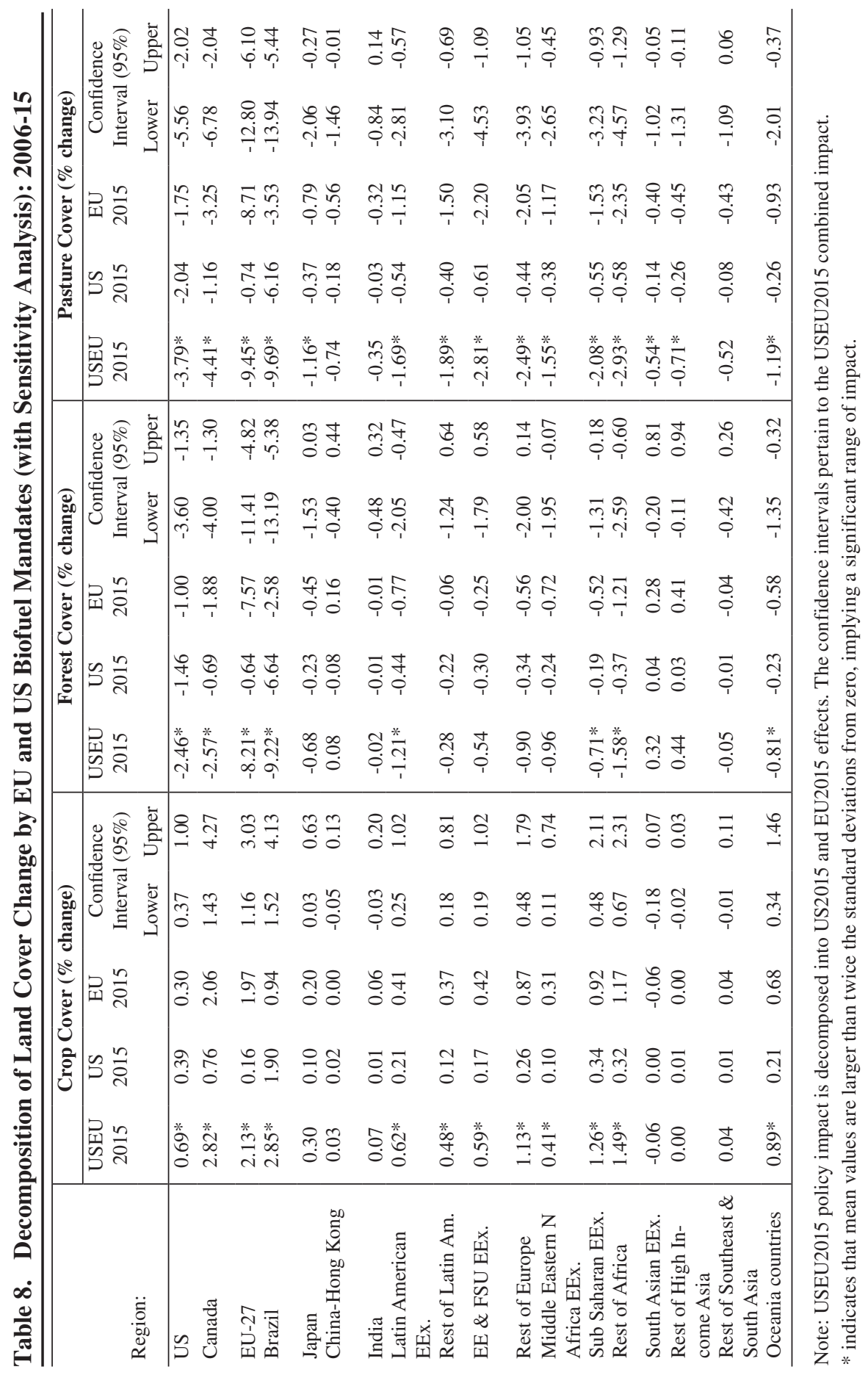


From an environmental point of view, the big issue is not which crops are grown, but how much cropland is demanded overall, and how much (and where) grazing and forestlands are converted to cropland. Table 8 reports the percentage changes in different land cover area as a result of the EU and US mandates, and Technical Appendix Figures A3 and A4 (see footnote 2) show the distribution of these land cover changes across AEZs and regions. As with the output changes in Table 5, we decompose this total into the portion due to each region's biofuels programs. From the first group of columns, we see that crop cover is up in nearly all regions. Here we also see quite a bit of interaction between the two sets of programs. For example, in the US, about half of the rise in crop cover is due to the EU programs. In the EU, the US programs account for only a small portion of the rise in crop cover, whereas, in Brazil, about two-third of the increase in crop cover $(2.85 \%)$ is due to US biofuel program. In other regions, the EU programs play the largest role in increasing crop cover. For example, in the Rest of Africa region, the EU programs account for nearly $1.2 \%$ of the total $1.5 \%$ rise in crop cover.

Where does this crop land come from? In our framework it is restricted to come from pastureland and accessible forest lands, since we do not take into account idle lands, nor do we consider the possibility of accessing currently inaccessible forests. Also, since we do not explicitly model land transitions from one cover type to another, we cannot say whether the new crop land is obtained directly from forest lands, or whether it is largely a result of conversion from high quality pastureland (this is our expectation), with the decline in forest land contributing to making up some of the lost grazing land. The largest net reduction in land cover tends to be in pasturelands (Table 8, final set of columns). For example, in Brazil, we estimate that pasturelands could decline by nearly $9.4 \%$ as a result of this global push for biofuels, of which $8.7 \%$ decline is from EU mandates alone. The largest percentage declines in accessible forest land cover are in Brazil and EU, followed by smaller changes in Canada, US, and Africa. In most other regions, the percentage decline in forest cover is rather small.

Welfare Impacts: It is also of interest to ask about the aggregate welfare impacts of the biofuel mandates on both the EU and US economies, as well as the rest of the world. Table 9 summarizes the money metric value of these changes in US\$ billions (measured as equivalent variation) and decomposes them into that portion attributable to changes in allocative efficiency and terms of trade. The efficiency changes reflect the cost of mandating producers to boost biofuel production from 2006 levels to 2015 mandated amounts in the absence of higher oil prices (recall that our 2006 baseline assumes $\$ 60 / \mathrm{bbl}$. oil). This efficiency loss is reflected in the USA and EU rows of the first column, along with second best interactions with other taxes and subsidies in the economy. These losses amount to $\$ 15$ billion in the US and $\$ 28$ billion in the EU. Apart from minor, second-best interactions with policies in other regions, these efficiency losses largely explain the global welfare loss from EU-US mandates. Of course, the magnitude of this loss hinges critically on the world price of petroleum. We estimate, for example, that at sustained oil prices of $\$ 126 / \mathrm{bbl}$., the US RFS mandate for 2015 would no 
Table 9. Welfare Changes due to US and EU Biofuel Mandates

\begin{tabular}{lccc}
\hline \multicolumn{3}{c}{$(2006-2015$ changes in US\$ billions) } \\
\hline Region: & Allocative Efficiency & Terms of Trade & Total Welfare Change \\
\hline USA & -15 & 7 & $\mathbf{- 8}$ \\
EU & -28 & 3 & $\mathbf{- 2 5}$ \\
Brazil & 1 & 4 & $\mathbf{5}$ \\
Japan & 1 & 2 & $\mathbf{2}$ \\
Oil Exporters & -2 & -22 & $\mathbf{- 2 4}$ \\
RoW & 1 & 6 & $\mathbf{7}$ \\
World & -43 & 0 & $\mathbf{- 4 3}$ \\
\hline
\end{tabular}

longer be binding, so that enforcement would entail no additional welfare cost.

The regional welfare impact of biofuel mandates depends not only on efficiency changes, but also on terms of trade changes. By dampening the global demand for petroleum products, these biofuel policies depress the world price of oil and thereby inflict a terms of trade loss on the oil exporters (Table 9, second column) of $\$ 22$ billion. However, unlike the efficiency effects, which change the size of the global economic "pie", the terms of trade effects are merely income transfers among regions. Thus the oil exporters' loss is the importers' gain. This benefits the US most, offsetting about half of the adverse efficiency effects in that region. As a result, the net welfare cost for the US of $\$ 8$ billion is actually rather small. In the EU, the terms of trade gain is smaller ( $\$ 3$ billion) and the efficiency cost of mandates is larger, so the EU welfare loss (\$25 billion) is three times as high as for the US.

Systematic Sensitivity Analysis: Given the uncertainty associated with the key parameters in this model, it is critical to undertake a systematic sensitivity analysis in which the model is re-solved for different draws from the underlying parameter distributions. Monte Carlo analysis is the standard approach to this problem. However, it is impractical for large scale models. Therefore, we adopt the Gaussian Quadrature approach proposed by DeVuyst and Preckel (1997), who show that it is highly efficient and a very close approximation to full-blown Monte Carlo analysis of a similar, global CGE model. Here, we follow the implementation by Pearson and Arndt (2000). We use symmetric triangular distributions to approximate the underlying distribution of the key parameters, which permits us to characterize the parameter distribution through the mean and lower end point.

Information about the assumed parameter distributions is reported in the Technical Appendix (footnote 2). We follow Keeney and Hertel (2008) in allowing the elasticity of crop yields with respect to price to vary from 0.00 to 0.80 , with mean 0.40 . Lower bounds on the absolute value of the acreage response parameters (elasticities of land transformation) are assumed to be $20 \%$ of the mean for both the land cover and harvested crop land elasticities. Finally, we also sample from the distribution of Armington trade elasticities, based on the estimated standard deviations from the source study for those estimates (Hertel et al., 2007). 
In total we vary eight parameters and we compute mean changes for all variables, as well as the associated confidence intervals.

Given the focus on land use in the debate over biofuels, we have chosen to focus here on the $(95 \%)$ confidence intervals for outputs, harvested area and land cover changes. So, in tables 5, 7 and 8, we have appended an * next to those changes that are significantly different from zero by this metric. Note that, with the exception of livestock and forestry in the US, all of the output changes in US, EU and Brazil are significantly different from zero. In the case of harvested area (Table 7), all the changes in US, EU and Brazil are significant, but for other regions, this is not always the case. Oilseeds area is the one column where all entries from all regions are significantly different from zero. This underscores the importance of EU biodiesel mandates for world oilseeds markets. Finally, we also report the $95 \%$ confidence interval for land cover changes, by region, in the final two columns of each section in Table 8. These correspond to the combined, EUUS-2015 experiment. So, for example, the confidence intervals on US crop cover ranges from $+0.37 \%$ to $+1 \%$ changes in the wake of the combined mandates. ${ }^{4}$ The crop cover confidence interval is even larger in the case of Canada and Brazil, but the lower bound is still large and positive. However, in most Asian economies, the sign of the impact on crop cover is uncertain. For example, in India, the confidence interval on crop cover change ranges from $-0.03 \%$ to $+0.2 \%$. Uncertainty in pasture cover is quite similar in the pattern of countries in which the sign of the land cover change is uncertain with respect to the parameter distributions in Technical Appendix Table A1 (see Footnote 2). However, forest cover uncertainty is more pervasive. Indeed, the only regions where we can say for certain that forest cover will decline in the context of the combined biofuel mandates are: USA, Canada, EU, Brazil, Latin American Energy Exporters, Africa, and Oceania.

While space limitations preclude presentation of further sensitivity analysis results in the text, it is also of interest to vary key parameters one-at-a-time to their lower and upper bounds, respectively. This allows us to ascertain which of these is most important in driving particular results. We present such tables in the Technical Appendix, tables A2 an A3 (see footnote 2). These results indicate that land cover changes are most sensitive to the yield elasticity and the cropland cover elasticity of transformation, which, in turn determines the supply elasticity of land to crop production (recall equation (2)).

\section{CONCLUSIONS}

Recently there has been a boom in research into the impact of biofuel programs on both domestic and global resource use. Previous authors have devoted considerable attention to the impacts of these policies on a country-by-country basis. However, there are also strong interactions between these programs, as they

4. These are confidence intervals around the mean land cover estimates which differ - but only very slightly - from the point estimates reported in the first column of Table 8 . To save space, we have only reported the point estimates. Typically these differ in the first or second decimal place. 
compete in world markets for feedstocks and ultimately for a limited supply of global land. In this paper, we have evaluated the interplay between two of the largest biofuels programs, namely the renewable fuel mandates in the US and the EU. We have also incorporated biofuels byproducts directly into the analysis.

We began with an analysis of the origins of the recent bio-fuel boom, using the historical period 2001-2006 for purposes of model validation. This was a period of rapidly rising oil prices, increased subsidies in the EU, and, in the US, there was a ban on the major competitor to ethanol for gasoline additives. Our analysis of this historical period permits us to evaluate the relative contribution of each of these factors to the global biofuel boom. We find that, in the US, the rising oil price was the most important contributor to the biofuel boom in that country, followed by the MTBE additive ban. In the EU, fuel tax exemptions were the most important factor in driving biofuel growth, followed by oil prices.

Our prospective analysis of the impacts of the biofuels boom on commodity markets focused on the 2006-2015 time period, during which existing investments and new mandates in the US and EU are expected to substantially increase the share of agricultural products (e.g., corn in the US, oilseeds in the EU, and sugar in Brazil) utilized by the biofuels sector. In the US, this share could more than double from 2006 levels, while the share of oilseeds going to biodiesel in the EU could triple. In analyzing the biofuel policies in these regions, we decompose the contribution of each set of regional policies to the global changes in output and land use. An interesting interaction between the two sets of policies is for oilseed production in the US, where much of the increase in output was due to EU policies. The other area where they have important interactions is in the aggregate demand for crop land. About one-third of the prospective growth in US crop cover, relative to baseline, is attributed to EU mandates.

When it comes to assessing the impacts of these mandates on other economies, the combined policies have a much greater impact than just the US or just the EU policies alone, with crop cover rising sharply in Latin America, Africa and Oceania as a result of the biofuel mandates. These increases in crop cover come at the expense of pasturelands (first and foremost) as well as commercial forests. It is these land use changes that have attracted great attention in the literature (e.g., Searchinger et al., 2008) and a logical next step would be to combine this global analysis of land use with estimates of the associated greenhouse gas emissions to explore these impacts in a more comprehensive fashion.

\section{REFERENCES}

Ahmed, A.S., T.W. Hertel, and R. Lubowski (2009). "Calibration of a Land Cover Supply Function Using Transition Probabilities". GTAP Research Memorandum No 14. Center for Global Trade Analysis, Purdue University, West Lafayette, IN, USA. Accessed at: https://www.gtap.agecon. purdue.edu/resources/res_display.asp?RecordID=2947

Banse M., H van Meijl, A. Tabeau, and G. Woltjer (2007). "Will EU Biofuel Policies Affect Global Agricultural Markets?” European Review of Agricultural Economics 35(2):117-141. 
Beckman, J.F. (2008). "Energy Policy Analysis in a Global Context: Applications to Biofuels, Livestock, and Feed" Dissertation (Unpublished) submitted to Purdue University, West Lafayette, IN, USA.

Birur, D.K., T.W. Hertel and W.E. Tyner (2007). "Impact of Biofuel Production on World Agricultural Markets: A Computable General Equilibrium Analysis." GTAP Working Paper No. 53, presented earlier at the $10^{\text {th }}$ Annual Conference on Global Economic Analysis, Purdue University, West Lafayette, IN, USA. Accessed at: https://www.gtap.agecon.purdue.edu/resources/res_display. asp?RecordID $=2413$

Brockmeier, M. (1996). “A Graphical Exposition of the GTAP Model," GTAP Technical Paper No. 8, Center for Global Trade Analysis, Purdue University, West Lafayette, IN, USA. Accessed at: https:// www.gtap.agecon.purdue.edu/resources/res_display.asp?RecordID $=311$

DeVuyst, E.A. and P.V. Preckel (1997). "Sensitivity Analysis Revisited: A Quadrature-Based Approach." Journal of Policy Modeling 19(2):175-85.

Eickhout, B. H., van Meijl, A. Tabeau, and E. Stehfest (2008). "The Impact of Environmental and Climate Constraints on Global Food Supply" GTAP Working Paper No. 47, Center for Global Trade Analysis, Purdue University, West Lafayette, IN, USA.

Espey, M. (1998). "Gasoline Demand Revisited: An International Meta-Analysis of Elasticities." Energy Economics, 20: 273-295.

European Biodiesel Board (2007). Data accessed at http://www.ebb-eu.org/stats.php

European Commission (2007). "Impact Assessment of the Renewable Energy Roadmap - March 2007," Directorate-General for Agriculture and Rural Development, European Commission, AGRI G-2/WMD(2007) Accessed at: http://ec.europa.eu/agriculture/analysis/markets/biofuel/ impact042007/text_en.pdf

FAPRI (2004). "Documentation the FAPRI Modeling System.” FAPRI-UMC Report \#12-04, Food and Agricultural Policy Research Institute, Iowa State University, University of Missouri-Columbia, Ames, IA, USA. December 2004.

Fargione J. et al. (2008). "Land Clearing and the Biofuel Carbon Debt." Science 319 (5867): 12351238.

Harrison, W. J., and K.R. Pearson (1994). "Computing Solutions for Large General Equilibrium Models using GEMPACK.” Impact Project Preliminary Working Paper No. IP-64.

Harrison, W.J., Horridge, J.M., and K.R. Pearson. (2000). "Decomposing Simulation Results with Respect to Exogenous Shocks". Computational Economics. 15(3): 227-249. doi: http://dx.doi. org/10.1023/A:1008739609685

Hertel, T.W. (1997). Global Trade Analysis, Modeling and Applications. Cambridge University Press, Cambridge.

Hertel, T.W., D. Hummels, M. Ivanic, and R. Keeney (2007). "How Confident Can We Be of CGE Analysis of Free Trade Agreements?" Economic Modeling, 24: 611-635.

Hertel, T.W., S. Rose and R. Tol (eds.) (2009). Economic Analysis of Land Use in Global Climate Policy. Routledge Press.

Hertel, T.W., H. Lee, S. Rose and B. Sohngen (2009). "Modeling Land-use Related Greenhouse Gas Sources and Sinks and their Mitigation Potential", Chapter 6 in Economic Analysis of Land Use in Global Climate Change Policy. Edited by T. Hertel, S. Rose and R. Tol. Routledge Press.

Keeney, R. and T.W. Hertel (2008). "Indirect Land Use Impacts of US Biofuels Policies: The Importance of Acreage, Yield and Bilateral Trade Responses". GTAP Working Paper No. 52, Center for Global Trade Analysis, Purdue University, West Lafayette, IN, USA. Accessed at: https://www.gtap. agecon.purdue.edu/resources/res_display.asp?RecordID $=2810$

Lee, H.-L., T.W. Hertel, S. Rose and M. Avetisyan (2009). "An Integrated Global Land Use Data Base for CGE Analysis of Climate Change Policy Options." Chapter 4 in Economic Analysis of Land Use in Global Climate Change Policy. Edited by T. Hertel, S. Rose and R. Tol. Routledge Press.

McCarl, B.A. et al. (2005). Potential for Biofuel-based Greenhouse Gas Emission Mitigation: Rationale and Potential. In: J. Outlaw and K. Collins (Eds.) "Agriculture as a Producer and Consumer of Energy". Cabi Publishing. pp. 368. 


\section{0 / The Energy Journal}

Monfreda, C., N. Ramankutty, and J.A. Foley (2008a). "Farming the Planet: 2. Geographic Distribution of Crop Areas, Yields, Physiological Types, and Net Primary Production in the Year 2000," Global Biogeochem. Cycles, 22, GB1022, doi:10.1029/2007GB002947.

Monfreda, C., N. Ramankutty, and T.W. Hertel (2008b). "Global Agricultural Land Use Data for Climate Change Analysis," Chapter 2 in T. Hertel, S. Rose and R. Tol (eds.) Economic Analysis of Land Use in Global Climate Policy, Routledge Press.

Pearson, K. and C. Arndt (2000) "Implementing Systematic Sensitivity Analysis Using GEMPACK." GTAP Technical Paper No. 3, Center for Global Trade Analysis, Purdue University. West Lafayette, IN, USA.

Powell, A.A. and F.H.G. Gruen (1968). "The Constant Elasticity of Transformation Production Frontier and Linear Supply System", International Economic Review, 9(3):315-328.

Ramankutty, N., A. Evan, C. Monfreda, and J.A. Foley (2008). "Farming the Planet: 1. Geographic Distribution of Global Agricultural Lands in the Year 2000." Global Biogeochemical Cycles, 22, GB1003, doi:10.1029/2007GB002952.

Renewable Fuels Association (2008). "Industry Statistics: Ethanol Industry Overview." Accessed at: http://www.ethanolrfa.org/industry/statistics/\#EIO

Lubowski, R., A.J. Plantinga, and R.N. Stavins (2006) "Land-Use Changes and Carbon Sinks: Econometric Estimation of the Carbon Sequestration Supply Function", Journal of Environmental Economics and Management, 51(2006).

Searchinger, T.D. et al. (2008). "Use of U.S. Croplands for Biofuels Increases Greenhouse Gases through Emissions from Land-Use Change." Science 319(5867): 1238-1240.

Searchinger, T.D., and R. Heimlich (2007). "Estimating Greenhouse Gas Emissions from Soy-based U.S. Biodiesel when Factoring in Emissions from Land Use Change." Paper presented at the Workshop on the Lifecycle Carbon Footprint of Biofuels, Farm Foundation and USDA, 28 January.

Sohngen, B., C. Tennity, M. Hnytka and K. Meeusen (2009). "Global Forestry Data for the Economic Modeling of Land Use", Chapter 3 in T. Hertel, S. Rose and R. Tol (eds.) Economic Analysis of Land Use in Global Climate Policy, Routledge Press.

Taheripour, F., D.K. Birur, T.W. Hertel, and W.E. Tyner (2007). "Introducing Liquid Biofuels into the GTAP Database.” GTAP Research Memorandum No. 11. Center for Global Trade Analysis, Purdue University, West Lafayette, IN, USA. Accessed at: https://www.gtap.agecon. purdue.edu/resources/ res_display.asp?RecordID $=2534$

Taheripour, F., T.W. Hertel, W.E. Tyner, J.F. Beckman and D.K. Birur (2008). "Biofuels and their ByProducts: Global Economic and Environmental Implications." Paper Presented at the $11^{\text {th }}$ Annual Conference on Global Economic Analysis held at Helsinki, Finland, during June 12-14, 2008.

Tokgoz, S. et al. (2007). "Emerging Biofuels: Outlook of Effects on U.S. Grain, Oilseed, and Livestock Markets." Staff report 07-SR 101, Center for Agricultural and rural Development, Iowa State University. Accessed at: http://www.card.iastate.edu/publications/synopsis.aspx?id=1050

Valenzuela E., T.W. Hertel, R. Keeney, and J.J. Reimer (2007). "Assessing Global CGE Model Validity using Agricultural Price Volatility.” American Journal of Agricultural Economics, 89(2):383-397. 